\title{
Retraction Note: Soft computing methodologies for estimation of energy consumption in buildings with different envelope parameters
}

\section{Sareh Naji • Shahaboddin Shamshirband • \\ Hamed Basser • U. Johnson Alengaram • \\ Mohd Zamin Jumaat • Mohsen Amirmojahedi}

Published online: 7 December 2018

(C) Springer Nature B.V. 2018

\section{Retraction Note: Energy Efficiency https://doi.org/10.1007/s12053-015-9373-Z}

The Editor-in-Chief has retracted this article (Naji et al. 2016a) because validity of the content of this article cannot be verified. This article showed evidence of substantial text overlap (most notably with the articles cited (Naji et al. 2014, 2016b; Akib et al. 2015)), peer review and authorship manipulation. None of the authors agree to this retraction.

\section{References}

Naji, S., Shamshirband, S., Basser, H., Alengaram, U. J., Jumaat, M. Z., \& Amirmojahedi, M. (2016a). RETRACTED ARTICLE: Soft computing methodologies for estimation of

The online version of the original article can be found at https://doi.org/10.1007/s12053-015-9373-z

S. Naji $(\bowtie) \cdot$ U. Johnson Alengaram • M. Z. Jumaat •

M. Amirmojahedi

Department of Civil Engineering, Faculty of Engineering,

University of Malaya, Kuala Lumpur, Malaysia

e-mail: sareh.naji@gmail.com

S. Shamshirband $(\triangle)$

Department of Computer System and Technology, Faculty of Computer Science and Information Technology, Kuala Lumpur, Malaysia

e-mail: shamshirband@um.edu.my

H. Basser

Faculty of Engineering, Seraj University, Tabriz, Iran energy consumption in buildings with different envelope parameters. Energy Efficiency, 9, 435-453. https://doi. org/10.1007/s12053-015-9373-z.

Naji, S., Shamshirband, S., Basser, H., Keivani, A., Alengaram, U. J., Jumaat, M. Z., \& Petković, D. (2016b). Application of adaptive neuro-fuzzy methodology for estimating building energy consumption. Renewable and Sustainable Energy Reviews, 53, 1520-1528. https://doi.org/10.1016/j.rser.2015.09.062.

Naji, S., Çelik, O. C., Alengaram, U. J., et al. (2014). Structure, energy and cost efficiency evaluation of three different lightweight construction systems used in low-rise residential buildings. Energy and Buildings, 84, 727-739. https://doi. org/10.1016/j.enbuild.2014.08.009.

Akib, S., Rahman, S., Shamshirband, S., \& Petković, D. (2015). Soft computing methodologies for estimation of bridge girder forces with perforations under tsunami wave loading. Bulletin of Earthquake Engineering, 13, 935-952. https://doi.org/10.1007/s10518-014-9656-3. 